Corrigendum

\title{
Corrigendum to "The Role of Costimulation Blockade in Solid Organ and Islet Xenotransplantation"
}

\author{
Kannan P. Samy, ${ }^{1}$ James R. Butler, ${ }^{1}$ Ping Li, ${ }^{1}$ David K. C. Cooper, ${ }^{2}$ and Burcin Ekser $\mathbb{D}^{1}$ \\ ${ }^{1}$ Division of Transplant Surgery, Department of Surgery, Indiana University School of Medicine, Indianapolis, IN, USA \\ ${ }^{2}$ Xenotransplantation Program, Department of Surgery, The University of Alabama at Birmingham, Birmingham, AL, USA \\ Correspondence should be addressed to Burcin Ekser; bekser@iupui.edu \\ Received 19 December 2017; Accepted 16 January 2018; Published 22 March 2018 \\ Copyright (@ 2018 Kannan P. Samy et al. This is an open access article distributed under the Creative Commons Attribution License, \\ which permits unrestricted use, distribution, and reproduction in any medium, provided the original work is properly cited.
}

In the article titled "The Role of Costimulation Blockade in Solid Organ and Islet Xenotransplantation" [1], there was an error in Figure 1 and its legend. The corrected figure is shown below. 


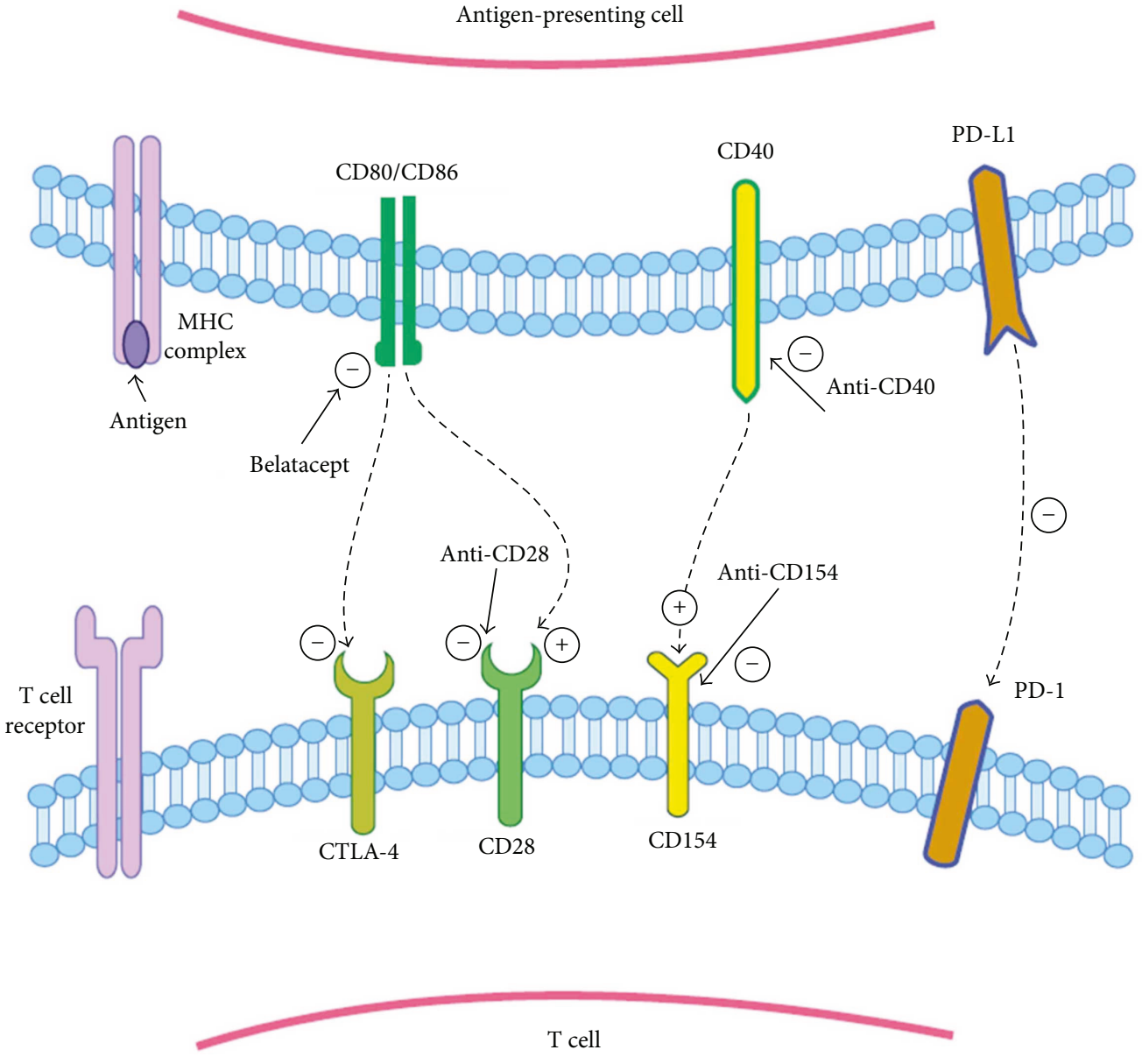

FIgURE 1: Costimulation pathways in T cell regulation. Upon MHC-antigen interaction with the TCR, costimulation pathways can augment or suppress the activation of the T cell. From left to right, CD28 is activated by CD80/CD86. CTLA-4 coinhibitor competes with CD28 for binding to CD80/CD86. CTLA-4Ig and belatacept work by taking advantage of their higher affinity to CD28 over CD80/CD86 and thereby block CD80/CD86 activation of CD28. CD154 and CD40 are other potent activators of T cells; monoclonal antibodies against either of these surface proteins have potential for application in transplant immunosuppression. PD-1 is expressed on T cells, and interaction with PD-1 ligand (PD-L1) produces a suppressive signal to the T cell.

\section{References}

[1] K. P. Samy, J. R. Butler, P. Li, C. DKC, and B. Ekser, "The role of costimulation blockade in solid organ and islet xenotransplantation," Journal of Immunology Research, vol. 2017, Article ID 8415205, 11 pages, 2017. 


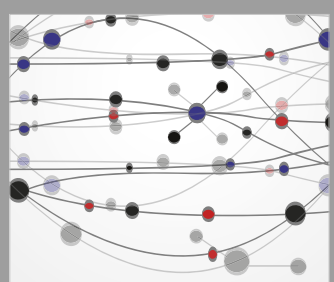

The Scientific World Journal
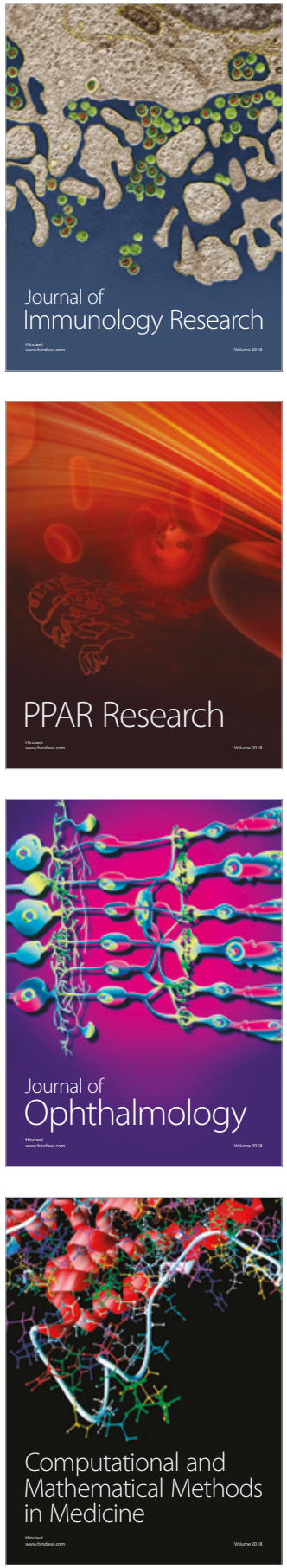

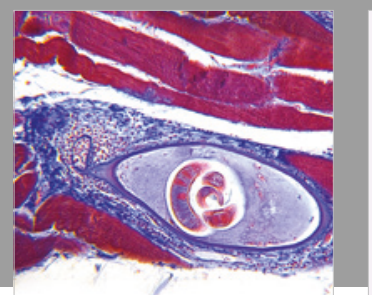

Gastroenterology Research and Practice

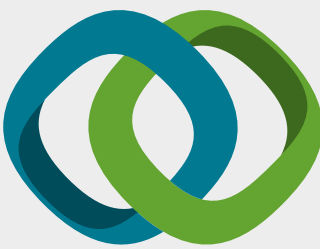

\section{Hindawi}

Submit your manuscripts at

www.hindawi.com
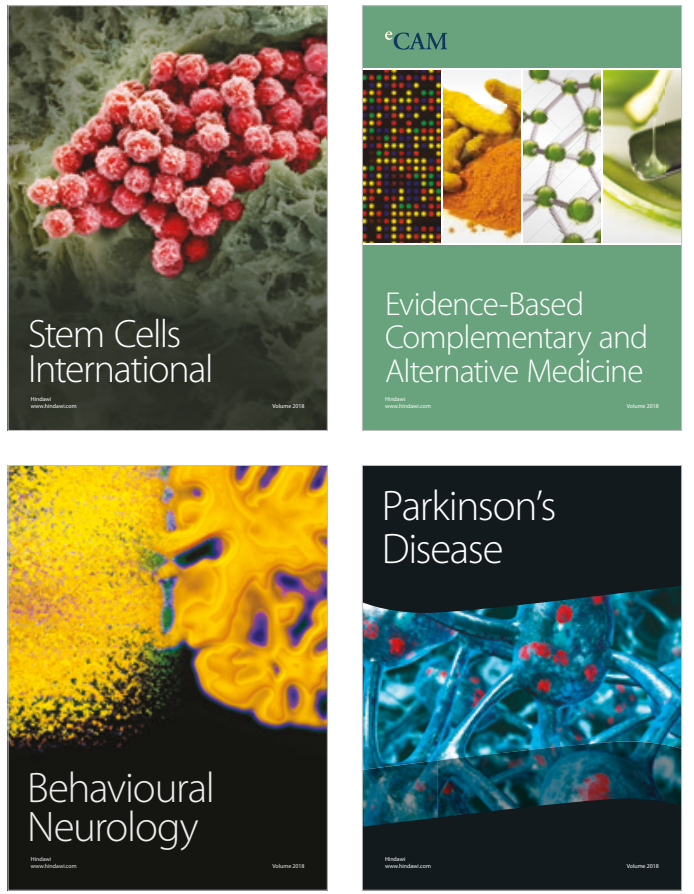

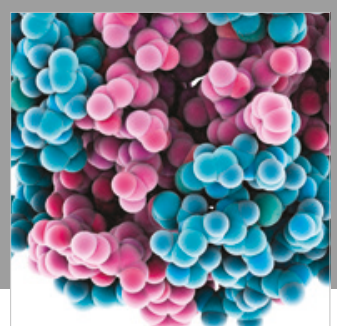

ournal of

Diabetes Research

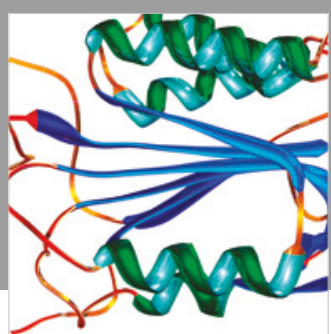

Disease Markers
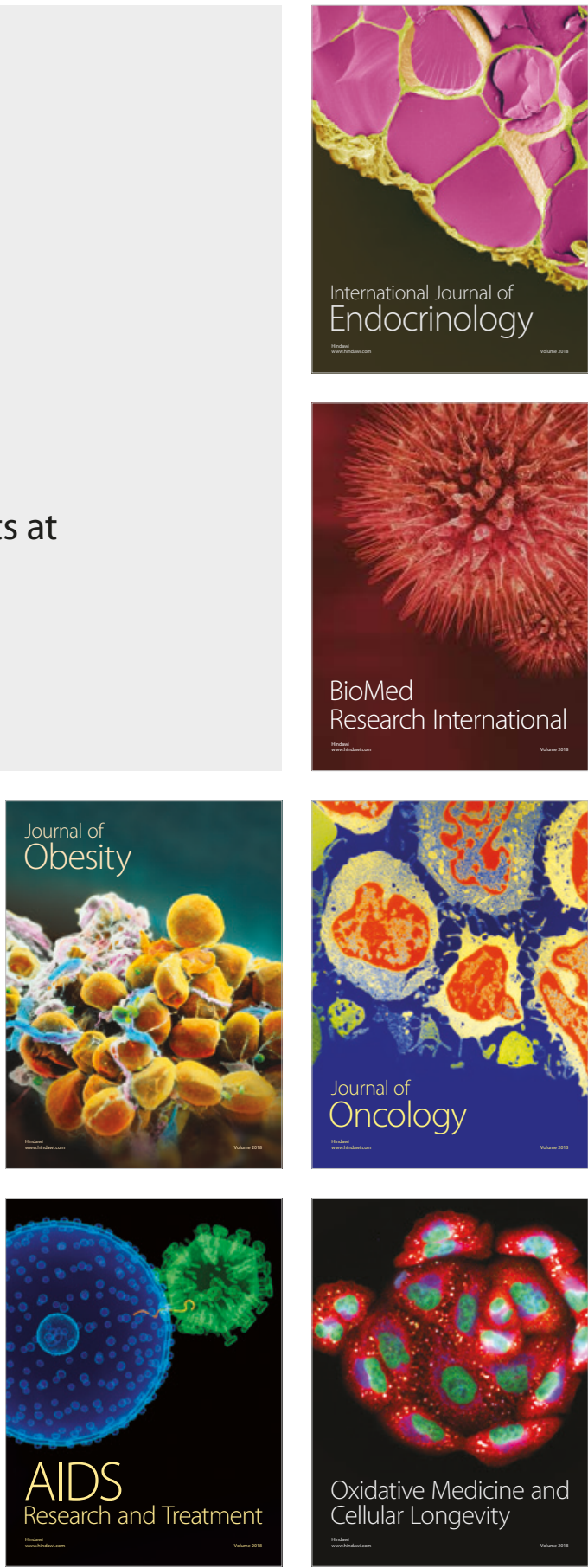